\title{
Birokrasi dan Perilaku Budaya Organisasi Di Pesantren
}

\author{
Nur Ita A’ini Qudwatal Millah ${ }^{1}$, Nove Kurniati Sari² \\ ${ }^{1}$ Universitas Islam Negeri Sunan Kalijaga Yogyakarta, Indonesia \\ ${ }^{2}$ Universitas Islam Negeri Sunan Kalijaga Yogyakarta, Indonesia \\ ${ }^{1}$ nuritaaini2095@gmail.com
}

\begin{abstract}
Abstrak:
Pembahasan pada tulisan kali ini difokuskan kepada birokrasi dan perilaku budaya organisasi dalam salah satu lembaga pendidikan Islam di Kota Yogyakarta. Dalam tulisan ini penulis terfokus pada Pondok Pesantren Al-Munawwir Komplek Q Krapyak Yogyakarta dalam mempertahankan dan memajukan eksistensinya terhadap pengimplementasian birokrasi kelembagaan dalam membangun perilaku dan budaya organisasi. Metode penelitian yang digunakan adalah studi deskriptif kualitatif. Teknik pengumpulan data dalam tulisan ini melalui observasi, wawancara, dan studi dokumentasi. Hasil dari penelitian ini menunjukkan bahwasanya keberhasilan lembaga pendidikan Islam tentunya tidak terlepas dari bagaimana peran birokrasi yang bersifat dialogis dalam pembagian struktur, tugas dan unsur kelembagaan yang dirumuskan melalui ruang diskusi ataupun musyawarah, perilaku serta budaya organisasi dengan sistem rolling job dan menanamkan sikap nilai moral keislaman serta mempertahankan budaya masyarakat Jawa dengan membiasakan berkomunikasi menggunakan bahasa daerah agar menanamkan nilai kebudayaan dengan membangun rasa ukhuwah dalam berorganisasi dalam ruang lingkup Pondok Pesantren Al-Munawwir Komplek Q Krapyak Yogyakarta.
\end{abstract}

Kata Kunci: Birokrasi, Perilaku Budaya, Pendidikan Islam, Pesantren

\begin{abstract}
:
The discussion in this article focuses on the bureaucracy and cultural behavior of the organization in one of the Islamic educational institutions in the city of Yogyakarta. In this paper the author focuses on Al-Munawwir Islamic Boarding School Complex Q Krapyak
\end{abstract}


Yogyakarta in maintaining and advancing its existence towards implementing institutional bureaucracy in building organizational behavior and culture. The research method used was a descriptive qualitative study. Data collection techniques in this paper through observation, interviews, and documentation studies. The results of this study indicate that the success of Islamic educational institutions certainly can not be separated from how the role of a dialogic bureaucracy in the distribution of structures, tasks and institutional elements that are formulated through discussion rooms or deliberations, behavior and organizational culture with a rolling job system and instill attitudes of Islamic moral values and preserving the culture of Javanese people by making it a habit to communicate using local languages to instill cultural values by building a sense of ukhuwah in organizing within the scope of the AlMunawwir Islamic Boarding School Complex Q Krapyak Yogyakarta

Keywords: Bureaucracy, Cultural Behavior, Islamic Education,

\section{Pendahuluan}

Sistem birokrasi adalah suatu komponen yang tidak bisa lepas dari kehidupan bermasyarakat saat ini. Baik pemerintahan baik aparatur administratif hingga ke sendi-sendi pendidikan, tidak dapat berjalan tanpa adanya birokrasi. Disinilah birokrasi menjadi sarana paling rasional sebagai kontrol atas tindakan manusia untuk mencapat derajat efisiensi tertinggi. Selain itu birokrasi adalah sarana bagi sebuah organisasi untuk merumuskan, melaksanakan, dan mengawasi berjalannya sebuah kebijakan yang telah disepakati bersama. Birokrasi tidak hanya menelurkan rumusan-rumusan kebijakan dan evaluasinya, namun juga mempengaruhi pola perilaku anggotanya serta nilai-nilai budaya organisasi yang berlaku di dalamnya. Dalam aspek ini, dapat dipahami bahwa birokrasi dalam lembaga pendidikan Islam bukanlah suatu produk statis, melainkan produk politik yang memiliki tujuan dalam memajukan sistem kelembagaannya, ideologinya, maupun personal-personal dalam kelompok $^{1}$.

Berdasarkan konsep di atas, birokrasi dalam lembaga pendidikan Islam memiliki fungsi ganda yaitu menjadi sarana untuk mempermudah pembagian struktur dan peran untuk menciptakan iklim kerja yang terarah, serta mampu membangun perilaku dan budaya yang sesuai dengan visi dan misi kelembagaan. Dalam mewujudkan harapan dan tujuan tersebut, tentu tidak lepas dari beberapa faktor seperti, peran seorang Pengasuh sebagai pimpinan dan

1 Hakam Ulfi, Model Kepemimpinan Birokrasi, dalam Dyah Mutiarin, Manajemen Birokrasi dan Kebijakan, (Yogyakarta: Pustaka Pelajar, 2014), hlm. 137. 
pengambil kebijakan yang dibantu Ketua Santri (Raisah) sebagai eksekutor dalam menggerakkan dan membangun sumber daya manusianya (pengurus dan seluruh warga pondok pesantren), bagaimana membangun relasi kerja (networking) yang baik dengan pengurus yang lainnya, serta memenuhi sarana dan prasarana penunjang bagi para santri.

Di dalam sebuah organisasi tentulah terdapat kebudayaan yang terbentuk berdasarkan pola perilaku anggota di dalamnya, di mana budaya dan perilaku organisasi akan mempengaruhi keefektifan organisasi. Secara garis besar dapat disimpulkan bahwa budaya organisasi yang kuat akan menjadikan anggota lebih puas, termotivasi dan memiliki komitmen yang besar terhadap organisasi. Dalam lembaga pendidikan Islam sendiri, budaya organisasi yang kuat akan dapat meningkatkan komitmen, antusiasme, dan loyalitas anggota terhadap lembaga tersebut. Kultur organisasi akan mempengaruhi perilaku anggota dan proses organisasi, sehingga budaya akan memunculkan tekanan pada orang-orang dalam organisasi untuk berpikir dan bertindak dengan cara yang konsisten dengan budaya yang ada.

Berangkat dari permasalahan tersebut, berbagai lembaga pendidikan tentunya menjadi sebuah tantangan menarik bagi pendidikan Islam itu tersendiri. Dalam hal ini Pondok Pesantren Al-Munawwir Krapyak Yogyakarta Komplek Q dalam mempertahankan dan memajukan eksistensinya. Oleh karenanya, keberhasilan lembaga pendidikan Islam tentulah tidaklah terlepas dari bagaimana peran birokrasi, perilaku manusia serta budaya organisasinya. Maka, penulis tertarik untuk mengkaji bagaimana pengelolaan birokrasi kelembagaan, perilaku manusianya dan langkah yang dilakukan dalam membangun budaya organisasinya dalam ruang lingkup lembaga pendidikan Islam Pondok Pesantren AlMunawwir Komplek Q Krapyak Yogyakarta.

\section{Pengertian Birokrasi}

Sedarmayanti mengungkapkan bahwa birokrasi merupakan sistem penyelenggaraan pemerintahan yang dijalankan pegawai negeri berdasarkan peraturan perundang-undangan. ${ }^{2}$ Birokrasi adalah struktur organisasi digambarkan dengan hierarki yang pejabatnya di angkat atau di tunjuk, garis tanggung jawab dan kewenangannya diatur oleh peraturan yang diketahui (termasuk sebelumnya), dan justifikasi setiap keputusan tentunya membutuhkan referensi

\footnotetext{
${ }^{2}$ Sedarmayanti, Sumber Daya Manusia dan Produktivitas Kerja (Bandung: CV. Mandar Maju, 2009), hlm. 67.
} 
untuk mengetahui kebijakan yang pengesahannya ditentukan oleh pemberi mandat di luar struktur organisasi itu sendiri. Lebih rinci lagi birokrasi dijabarkan sebagai organisasi yang memiliki jenjang, setiap jenjang diduduki oleh pejabat yang ditunjuk/diangkat, disertai aturan tentanng kewenangan dan tanggung jawabnya, dan setiap kebijakan yang dibuat harus diketahui oleh pemberi mandat. Istilah birokrasi pertama kali dikemukakan oleh Martin Albrow sebagai bentuk pemberian atribut terhadap istilah yang dipergunakan oleh seorang phsyiocrat Perancis Vincent de Gourney yang untuk pertama kalinya memakai istilah birokrasi dalam menguraikan sistem Pemerintahan Prusia di tahun $1745^{3}$.

Berdasarkan definisi yang dikemukakan oleh beberapa ahli birokrasi merupakan suatu sistem kontrol dalam organisasi yang dirancang berdasarkan aturan-aturan yang rasional dan sistematis, dan bertujuan untuk mengkoordinasi dan mengarahkan aktivitas-aktivitas kerja individu dalam rangka penyelesaian tugas-tugas administrasi berskala besar. Pengertian birokrasi juga dapat dilihat dalam bentuk jenis atau karakteristik dari birokrasi itu sendiri, namun para pakar ilmu sosial masing-masing memiliki definisi yang berbeda-beda. Birokrasi menurut Max Weber ${ }^{4}$ merupakan suatu organisasi besar yang memiliki otoritas legal rasional, legitimasi, ada pembagian kerja dan bersifat imperasional.

Birokrasi berkembang sejalan dengan perkembangan politik maupun ekonomi suatu masyarakat. Semakin modern suatu masyarakat, dalam arti semakin demokratis dan semakin makmur ekonomi mereka, akan semakin banyak tuntutan baru. Berkembangnya jaringan birokrasi (bureaucratization) adalah upaya memenuhi tuntutan baru tersebut ${ }^{5}$. Dalam terminologi ilmu politik, setidaknya dikenal empat model birokrasi yang umumnya ditemui dalam praktek pembangunan dunia ketiga, yaitu Weberian, Parkinsonan, Jacksonian, dan Orwellian $^{6}$. Namun dari keempat teori tersebut yang akan dijelaskan dalam makalah ini adalah model birokrasi Weberian serta konsep dasar birokrasi oleh Martin Albrow.

Model birokrasi Weberian digagas oleh Max Weber, seorang tokoh penting yang menjelaskan konsep birokrasi modern. Weberian menunjuk model birokrasi yang memfungsikan birokrasi sehingga memenuhi kriteria-kriteria ideal birokrasi Weber. Setidaknya ada 7 (tujuh) kriteria-kriteria ideal birokrasi yang digambarkan Max Weber, yaitu: 1) adanya pembagian kerja yang jelas; 2) hierarki kewenangan yang jelas; 3 ) formalisasi yang

\footnotetext{
${ }^{3}$ Miftah Thoha, Birokrasi dan Politik di Indonesia, cet. 2, (Jakarta: Raja Grafindo Persada, 2003), hlm. 9

${ }^{4}$ Max Weber, From Max Weber: Essays in Sociology, H. Gerth and C. Wright Mills, eds., (New York: Oxford University Press, 1947), hlm. 328.

${ }^{5}$ Riswanda Imawan, Membedah Politik Orde Baru, (Yogyakarta: Pustaka Pelajar, 1998), hlm. 85.

${ }^{6}$ Eep Saefulloh Fatah, Catatan Atas Gagalnya Politik Orde Baru, (Yogyakarta: Pustaka Pelajar, 1998), hlm. 192.
} 
tinggi; 4) bersifat tidak pribadi (impersonal); 5) pengambilan keputusan mengenai penempatan pegawai yang didasarkan atas kemampuan; 6) jejak karir bagi para pegawai; dan 7) kehidupan organisasi yang dipisahkan dengan jelas dari kehidupan pribadi ${ }^{7}$. Kemudian Martin Albrow ${ }^{8}$ menawarkan tujuh konsep birokrasi yang meliputi; 1) birokrasi sebagai organisasi sosial, 2) birokrasi sebagai inefisiensi organisasi, 3) birokrasi sebagai kekuasaan yang dijalankan oleh pejabat, 4) birokrasi sebagai administrasi negara (publik), 5) birokrasi sebagai administrasi yang dijalankan oleh pejabat, 6) birokrasi sebagai sebuah organisasi, dan 7) birokrasi sebagai masyarakat modern.

Birokrasi merupakan sebuah organisasi dalam pemerintahan yang merupakan rantai administrasi untuk mendukung pencapaian tujuan pemerintahan itu sendiri, yaitu pelayanan kepada masyarakat. Organisasi yang baik, efektif, efisien serta sesuai dengan kebutuhan, harus didasarkan pada asas-asas yang diterapkan dalam organisasi tersebut dengan kata lain birokrasi yang baik harus didasarkan pada asas-asas yang diterapkan. Berikut ini merupakan asas-asas kepemerintahan yang baik menurut Sedarmayanti ${ }^{9}$, yaitu mengikutsertakan semua masyarakat, transparan dan bertanggung jawab, efektif dan adil, menjamin adanya supremasi hukum, menjamin prioritas-prioritas politik, sosial dan ekonomi berdasarkan pada konsensus masyarakat, serta memerhatikan kepentingan mereka yang paling miskin dan lemah dalam proses pengambilan keputusan, termasuk menyangkut alokasi sumber daya pembangunan.

Senada dengan Sedarmayanti, Miftah Thoha juga menjabarkan tipe ideal birokrasi yang rasional, di mana ia menggabungkan dua teori birokrasi rasional terkemuka yaitu Weber dan Albrow dalam bentuk yang lebih up to date dengan kondisi saat ini yang juga menjadi dasar dari mini riset kami dalam mengukur Peranan Pemimpin Pendidikan Islam Terhadap Efektifitas Birokrasi Pendidikan Islam. Tipe ideal birokrasi yang rasional oleh Miftah Thoha ${ }^{10}$, yakni:

1) Individu pejabat secara personal bebas, akan tetapi dibatasi oleh jabatanya manakala ia menjalankan tugas-tugas atau kepentingan individual dalam jabatannya.

2) Jabatan-jabatan itu disusun dalam tingkatan hierarki dari atas kebawah dan kesamping. Konsekuensinya ada jabatan atasan dan bawahan, dan ada pula yang menyandang kekuasaan lebih besar dan ada yang lebih kecil.

3) Tugas dan fungsi masing-masing jabatan dalam hierarki itu secara spesifik berbeda satu sama lain.

\footnotetext{
${ }^{7}$ Stephen P. Robbins, Teori Organisasi: Struktur, Desain, dan Aplikasi, (Jakarta: Penerbit Arcan, 1994), hlm. 338.

${ }^{8}$ Martin Albrow, Birokrasi, Terj. M. Rusli Karim, (Yogyakarta: Tiara Wacana, 1996), hlm. 82-100.

${ }^{9}$ Sedarmayanti, Sumber Daya Manusia dan Produktivitas Kerja (Bandung: CV. Mandar Maju, 2009), hlm. 277.

${ }^{10}$ Miftah Thoha, Birokrasi dan Politik di Indonesia, cet. 2, (Jakarta: Raja Grafindo Persada, 2003), hlm 17.
} 
4) Setiap pejabat layaknya mempunyai kontrak jabatan yang harus dijalankan. Uraian tugas (job description) masing-masing pejabat merupakan domain yang menjadi wewenang dan tanggung jawab yang harus dijalankan sesuai dengan kontrak.

5) Setiap pejabat diseleksi atas dasar kualifikasi profesionalitasnya, idealnya dilakukan melalui ujian kompetitif.

6) Terdapat struktur pengembangan karir yang jelas dengan promosi berdasarkan senioritas dan merit sesuai dengan pertimbangan yang objektif.

7) Setiap pejabat sama sekali tidak dibenarkan menjalankan jabatannya dan resources instansinya untuk kepentingan pribadi dan keluarganya.

8) Setiap pejabat berada di bawah pengendalian dan pengawasan suatu sistem yang dijalankan secara disiplin.

\section{Birokrasi Pendidikan Islam}

Wilayah pendidikan secara administratif dan secara keilmuan harus sesuai dengan bidang pendidikan yang ditekuni, karena dalam perumusan kerja dan kebijakan sangat mempengaruhi hasil (outcome). Disisi lain, realitas menyajikan bahwa tidak semua jenis dan jenjang pekerjaan dijalankan oleh orang yang sesuai kompetensi dan keahliannya. Pandangan tersebut, sejalan dengan kritik Lynes yang memandang bahwa birokrasi tidak berjalan sendiri secara rasional, karena banyak dipengaruhi oleh kepentingan-kepentingan politik, kelompok maupun individu, sebab birokrasi itu sendiri merupakan produk dari proses politik ${ }^{11}$. Pandangan di atas, menunjukkan bahwa birokrasi bukanlah suatu lembaga netral yang tidak terlibat dengan tujuan-tujuan lain, karena birokrasi akan sangat lekat dengan tujuan politik, ideologi, kelompok, individu dan lain sebagainya.

Berangkat dari paradigma dan konsep birokrasi di atas, tujuan birokrasi dalam lembaga pendidikan Islam adalah: Pertama, penyusunan struktur pelaksana dan pembagian tugas kerja. Kedua, merumuskan dan menetapkan agenda-agenda lembaga yang akan dijalankan. Ketiga, pelaksanaan agenda kerja yang mengarah pada program kelembagaan yang telah direncanakan. Keempat, pengembangan program kerja dan program-program kelembagaan lainnya. Kelima, pendampingan pelaksanaan program kerja oleh kepala sekolah

${ }^{11}$ Djunawir Syafar Birokrasi, Perilaku dan Budaya Organisasi dalam Lembaga Pendidikan Islam Roudlotul Athfal UIN Sunan Kalijaga Yogyakarta, Manageria: Jurnal Manajemen Pendidikan Islam Vol 2, NO 2, November 2017, hlm. 275 
atau pemegang wewenang. Keenam, evaluasi sebagai bentuk kontrol dan tindak lanjut dari program kerja yang sudah dilaksanakan ${ }^{12}$.

Untuk memahami bagaimana peta konsep budaya organisasi dalam lembaga pendidikan Islam, pemakalah menggunakan teori Fons Tropenaars, sebagaimana yang dikutip Wirawan, menurut Fons Tropenaars budaya organisasi seperti bawang bombai yang terdiri atas tiga lapisan, sebagaimana dalam skema di bawah ini.

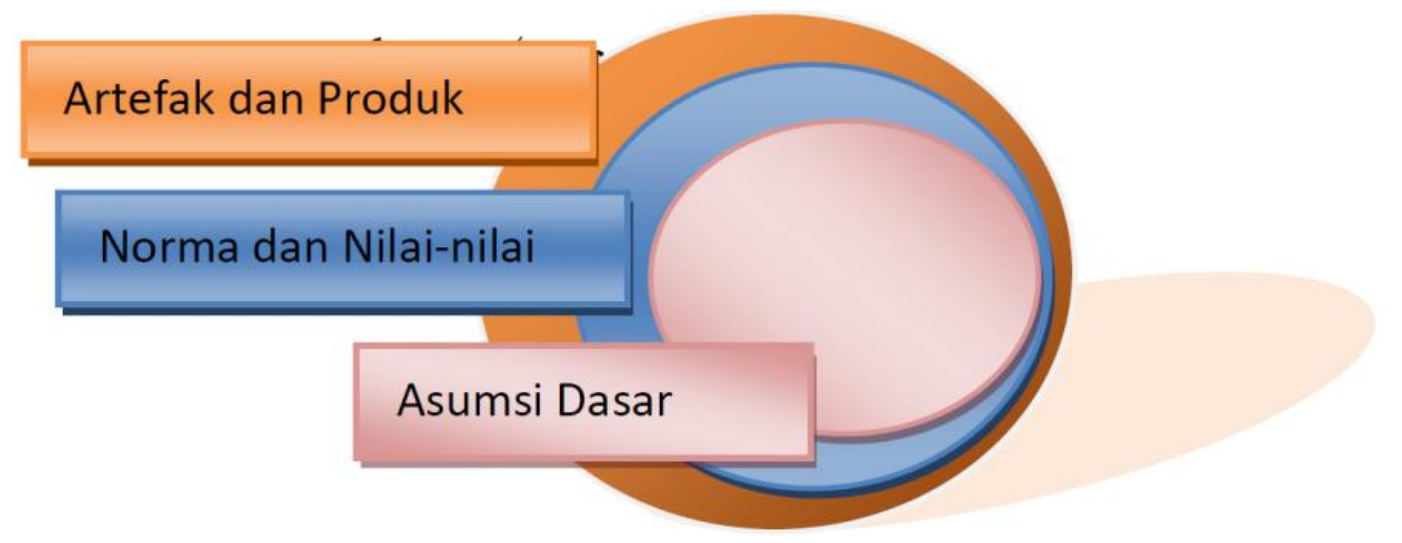

Model Budaya organisasi: Bawang Bombai (Fons Tropenaars) ${ }^{13}$

Model budaya organisasi bawang bombai yang dijelaskan Fons Tropenaars di atas, terdiri atas tiga lapisan sebagai berikut ${ }^{14}$ :

1. Lapisan paling luar (eksplisit), merupakan realitas yang dapat diobservasi, terdiri atas artefak-artefak dan produk-produk. Isi dari lapisan budaya organisasi ini mencakup bahasa (komunikasi), bangunan (bisa beruapa bangunan sekolah, tempat ibadah dan sebagainya), serta pakaian dan kesenian.

2. Lapisan tengah merupakan norma dan nilai-nilai. Pada bagian ini, budaya eksplisit dapat merefleksikan norma atau nilai-nilai. Norma tersebut merupakan rasa bersama yang dimiliki kelompok mengenai apa yang benar dan apa yang salah. Nilai-nilai tersebut menentukan definisi apakah sesuatu itu lebih baik atau buruk, dan karenannya dengan ideide yang dianut bersama oleh kelompok. Misalnya, budaya yang diyakini lembaga tersebut menanamkan rasa toleransi, sehingga jika ada sesuatu yang dianggap berlainan dengan norma, maka rasa toleransi tersebut menjadi penengah dari perbedaan tersebut.

\footnotetext{
${ }^{12}$ Djunawir Syafar Birokrasi, Perilaku dan Budaya Organisasi dalam Lembaga Pendidikan Islam Roudlotul Athfal UIN Sunan Kalijaga Yogyakarta ... hlm. 277. hlm. 13

${ }^{13}$ Wirawan, Budaya dan Iklim Organisasi: Teori, Aplikasi dan Penelitian, (Jakarta: Salemba Empat, 2007). 15.

${ }^{14}$ Wirawan, Budaya dan Iklim Organisasi: Teori, Aplikasi dan Penelitian, (Jakarta: Salemba Empat, 2007), hlm. 13-
} 
3. Lapisan inti (implisit), pada tahapan ini anggota dalam sistem organisasi bagaimana mengorganisasi dirinya dan mengembangkan cara yang paling efektif untuk menghadapi tantangan lingkungannya baik dengan memanfaatkan sumber-sumber yang telah ada maupun menggunakan metode tersendiri. Sehingga, bagaimana pola perilaku manusia bertindak dalam menghadapi tantangan.

Secara garis besar, bahwa teori dan konsep mengenai budaya organisasi di atas, relevansinya dengan nilai-nilai pendidikan Islam mengandung beberapa dimenasi penting sebagai berikut: Pertama, adanya perbedaan nilai yang membedakan antara lembaga pendidikan Islam dengan lembaga-lembaga lainnya, yang tentunya menunjukkan tujuan dari lembaga pendidikan Islam tersebut. Kedua, simbol seperti simbol yang bisa diindera misalnya pakaian, produk lembaga, dan sebagainya. Ketiga, pola interaksi sosial, baik berupa komunikasi, pergaulan dan sikap ${ }^{15}$.

\section{Perilaku Organisasi Pendidikan Islam}

Mempelajari perilaku organisasi berarti mempelajari perilaku para anggota organisasi, baik secara individu maupun kelompok. Mempelajari perilaku organisasi bukan mempelajari bagaimana organisasi itu berperilaku, tetapi mempelajari bagaimana para anggota organisasi berperilaku berarti berusaha memahami perilaku manusia. Memahami perilaku manusia adalah suatu hal yang sulit karena setiap manusia sebagai individu mempunyai perilaku berbeda-beda. Demikian pula perilaku manusia dipengaruhi oleh berbagai faktor; antara lain faktor lingkungan, latar belakang dan sebagainya. Dengan demikian perilaku manusia dipengaruhi oleh dua faktor, yaitu faktor dari dalam dan faktor dari luar.

1. Perilaku intern, adalah perilaku-perilaku yang dipengaruhi oleh faktor genetika, yaitu segala hal yang dibawa sejak orang itu lahir sehingga merupakan warisan dari orang tuanya.

2. Perilaku ekstern, adalah perilaku yang dipengaruhi oleh faktor luar, misalnya faktor lingkungan. Yang dimaksud dengan faktor lingkungan ialah segenap situasi dan kondisi yang dihadapi sehari-hari oleh seseorang dalam hidupnya ${ }^{16}$.

Dapat disimpulkan bahwa perilaku organisasi adalah studi tentang apa yang dilakukan orang-orang dalam organisasi dan bagaimana perilaku tersebut mempengaruhi kinerja

\footnotetext{
15 Djunawir Syafar Birokrasi, Perilaku dan Budaya Organisasi dalam Lembaga Pendidikan Islam Roudlotul Athfal UIN Sunan Kalijaga Yogyakarta, Manageria: Jurnal Manajemen Pendidikan Islam Vol 2, NO 2, November 2017, hlm. 280

${ }^{16}$ Wursanto, Dasar-dasar Ilmu Organisasi, (Yogyakart; Andi Offset, 2005), hlm. 275.
} 
organisasi ${ }^{17}$. Oleh karena itu di dalam organisasi terdapat orang-orang yang bekerja sama, maka secara otomatis organisasi tidak dapat dipisahkan dengan 'perilaku' orang-orang yang melakukan aktivitas di dalam organisasi dalam mereka mencapai tujuannya ${ }^{18}$. Perilaku organisasi (sering disingkat sebagai $\mathrm{OB}$ ) adalah suatu bidang studi yang mempelajari dampak perseorangan, kelompok, dan struktur pada perilaku dalam organisasi dengan maksud menerapkan pengetahuan tentang hal-hal tersebut demi perbaikan efektivitas organisasi. ${ }^{19}$

\section{Budaya Organisasi Pendidikan Islam}

Salah satu faktor yang membedakan suatu lembaga pendidikan Islam dengan lembaga lainnya adalah budayanya. Hal-hal tersebut penting, dan karena itu perlu dipahami serta dikenali. Akan tetapi, hal-hal yang bersifat universal itu harus diterapkan oleh manajemen dengan pendekatan yang memperhitungkan secara matang faktor-faktor situasi, kondisi, waktu, dan ruang. Oleh karenanya, diterapkan sesuai budaya yang berlaku dan dianut dalam organisasi yang bersangkutan ${ }^{20}$.

Budaya dalam lembaga pendidikan Islam merupakan sesuatu yang mempengaruhi tingkat pengetahuan meliputi sistem ide yang terdapat dalam pikiran manusia dalam kehidupan sehari-hari yang bersifat abstrak. Adapun perwujudan budaya berupa benda yang diciptakan oleh manusia sebagai makhluk berbudaya, berupa prilaku dan benda-benda yang bersifat nyata, misalnya pola perilaku, bahasa, peralatan hidup, organisasi sosial, religi, seni, dan lainnya, yang ke semuanya ditunjukkan untuk membantu manusia melangsungkan kehidupan masyarakat ${ }^{21}$.

Budaya adalah segala nilai, pemikiran, serta simbol yang memengaruhi perilaku, sikap, kepercayaan, serta kebiasaan seseorang dan masyarakat ${ }^{22}$. Pada awalnya, pemimpin lembaga pendidikan Islam pasti memiliki visi, misi dan tujuan tertentu yang diberikan setiap elemen yang ada di lembaga pendidikan Islam. Seorang pemimpin memberi contoh, kemudian diikuti bawahan. Akhirnya kebiasaan-kebiasaan tersebut akan menjadi budaya jika semuanya, baik pemimpin maupun bawahan memperaktikannya ${ }^{23}$. Adapun kaitannya dengan peran

${ }^{17}$ Syamsir Torang, Metode Riset Struktur dan Perilaku Organisasi, (Bandung: CV Pustaka, 2012), hlm. 112.

${ }^{18}$ Syamsir Torang, Metode Riset Struktur dan Perilaku Organisasi hlm. 112.

${ }^{19}$ Khaerul Umam, Perilaku Organisasi Cetakan I, (Bandung: Pustaka Setia, 2010), hlm. 30.

${ }^{20}$ Sondang P. Siagian, Kiat Meningkatkan Produktivitas Kerja, (Jakarta: Penerbit Rineka Cipta, 2002), hlm.187

${ }^{21}$ U. Saefullah, Manajemen Pendidikan Islam, (Bandung: Pustaka Setia, 2012), hlm. 88

22 Ujang Sumarwan, Perilaku Konsumen: Teori dan Penerapannya dalam Pemasaran. (Jakarta: Penerbit Ghalia Indonesia, 2003), hlm.170 hlm.60

${ }^{23}$ Didin Hafidhuddin dan Hendri Tanjung, Manajemen Syariah dalam Praktik, (Jakarta: Gema Insani Press, 2003), 
budaya organisasi di lembaga pendidikan Islam, menurut Purwanto, budaya organisasi memiliki lima peran, yaitu ${ }^{24}$ :

1. Budaya memberikan rasa memiliki identitas dan kebanggaan bagi karyawan, yaitu menciptakan perbedaan yang jelas antara organisasinya dengan yang lain;

2. Budaya mempermudah terbentuknya komitmen dan pemikiran yang lebih luas daripada kepentingan seseorang;

3. Memperkuat standar perilaku organisasi dalam membagun pelayanan superior pada pelanggan;

4. Budaya menciptakan pola adaptasi;

5. Membangun sistem kontrol organisasi secara menyeluruh.

Riset mengemukakan bahwa ada tujuh dimensi yang secara keseluruhan menangkap hakekat budaya sebuah organisasi. Dalam bukunya yang lain, Robbins menjelaskan tujuh dimensi budaya organisasi sebagai berikut ${ }^{25}$ :

1. Inovasi dan Mengambil resiko. Tingkat di mana para karyawan didorong untuk bersikap inovatif dan mengambil resiko

2. Perhation kepada detail. Tingkat di mana para karyawan diharapkan untuk menampilkan ketepatan, analisis, dan perhatian terhadap detail.

3. Orientasi hasil. Tingkat di mana para manajer memusatkan perhatian pada hasil-hasil bukannya pada teknik-teknik dan proses-proses yang digunakan untuk mencapai hasil-hasil itu.

4. Orientasi manusia. Tingkat di mana keputusan-keputusan manajemen memperhitungkan pengaruh hasil-hasil terhadap manusia di dalam organisasi itu.

5. Orientasi tim. Tingkat di mana kegiatan-kegiatan kerja disusun sekitar tim-tim bukan individu-individu.

6. Agresivitas. Tingkat di mana orang bersifat agresif dan bersaing bukannya ramah dan bekerja sama.

7. Stabilitas. Tingkat di mana kegiatan-kegiatan organisasi menekankan usaha mempertahankan status quo bukan pertumbuhan.

Dalam Islam, Rasulullah SAW sebagai panutan umat Muslimin, memandang orang lain sebagai manusia yang utuh dan dianggap sebagai sahabat atau kawan, termasuk kepada pembantunya sendiri. Rasulullah SAW tidak menganggap pembantunya sebagai bawahan

${ }^{24}$ Ngalim Purwanto, Budaya Perusahaan, (Yogyakarta: Pustaka Pelajar, 2008), hlm.26

25 Stephen P. Robbins, dan Mary Coulter, Manajemen, Edisi Bahasa Indonesia, Sixth Edition, (Jakarta: PT.Prenhallindo, 1999), hlm. 76-77. 
tetapi merupakan saudara bagi beliau, sehingga apa yang beliau makan dan beliau pakai tidak berbeda dengan apa yang dimakan dan dipakai oleh pembantunya. Jika pimpinan lembaga pendidikan mampu meniru sikap yang dicontohkan oleh Rasulullah SAW ini tentu akan memberikan pengaruh yang berbeda di lembaga pendidikan Islam. Iklim kerja akan terasa nyaman dan dapat memunculkan berbagai macam kreativitas-kreativitas baru yang dimunculkan oleh anggota lembaga pendidikan Islam. Namun jika bawahan berada di bawah tekanan yang begitu kuat dari pimpinan, maka seorang bawahan tidak akan berprestasi dan hanya akan mengerjakan apa yang menjadi kewajibannya ${ }^{26}$.

Begitu pentingnya budaya organisasi di lembaga pendidikan Islam, bisa tercerminkan dari keberhasilan Rasulullah SAW dalam membentuk suasana kerja yang nyaman kepada para sahabatnya, hal ini disebabkan oleh sikap beliau yang sangat penyayang kepada seluruh umatnya. Pada awal kemunculannya, budaya organisasi yang dibentuk di lembaga pendidikan Islam biasanya mengacu pada visi, misi, dan tujuan pendiriannya yang dipengaruhi oleh citacita internal dan tuntutan eksternal yang melingkupinya, sebagai sebuah fenomena kelompok, proses kemunculan budaya memakan waktu yang cukup lama dan pada umumnya melibatkan seorang tokoh (pimpinan puncak) yang mengintroduksikan visi dan misi kepada stafnya, kemudian dijadikan acuan oleh seluruh anggota kelompok ${ }^{27}$.

Budaya organisasi yang terbentuk di lembaga pendidikan Islam pada dasarnya memakan waktu yang tidak sebentar dan tidak jarang yang naik turun dalam proses pembentukannya. Namun, pada hakikatnya budaya organisasi yang terbentuk di lembaga pendidikan Islam merupakan hasil pengalaman setiap elemen secara kumulatif dari pendirinya dan juga dari lingkungan masyarakat sejak lembaga tersebut berdiri hingga saat ini.

\section{Profil Pondok Pesantren Al-Munawwir Komplek Q Krapyak Yogyakarta}

Pondok Pesantren Krapyak Yogyakarta yang semula hanya terdiri dari bangunan sederhana tempat tinggal santri dan ruang belajar, dalam perkembangannya dilengkapi dengan masjid serta sejumlah sekolah maupun madrasah. Regenerasi sepeninggal KH. M. Munawwir juga semakin memantik berdirinya cabang-cabang dengan pilihan program pendidikan yang variatif. Setelah bangunan pondok pesantren selesai dibuat dan mulai ditempati untuk mengajar Al-quran, tahap selanjutnya KH. M. Munawwir memprakarsai pembangunan masjid

\footnotetext{
${ }^{27}$ Aan Komariah dan Chepi Triatna, Visionary Leadership: Menuju Sekolah Efektif, (Bandung: Bumi Aksara, 2006), hlm.112.
}

26 Didin Hafidhuddin dan Hendri Tanjung, Manajemen Syariah dalam Praktik, (Jakarta: Gema Insani Press, 2003), hlm. 61 
dengan cara dibantu oleh masyarakat sekitar. Pembangunan berjalan terus sampai tahun 1927. Kembali setelah itu pembangunan diteruskan dengan membangun komplek santri dari tahun 1929 sampai $1930 .^{28}$

Pada dekade awal 1990-an santri Pondok Pesantren Krapyak telah mengalami pertambahan signifikan. Kemajuan juga terlihat pada pengajaran kitab kuning dengan tetap berpedoman pada tradisi salaf. Pada era ini pengajian kitab kuning diakomodasi dalam beberapa madrasah. Hal itu terdiri dari Madrasah Salafiyah I, II, III, IV, dan V, perguruan tinggi ilmu salaf Al-Ma'had Al-'Aly, Majelis Ta'lim dan Majelis Masyayikh. Dalam perkembangan terakhirnya, untuk menunjang kemampuan IPTEK santri berdampingan dengan pengajaran agama, pada tahun 2004 PP. Al-Munawwir bekerja sama dengan SMK Ma'arif I Kretek Bantul membuka Sekolah Menengah Kejuruan (SMK) dengan jurusan otomotif dan tata busana. Bersamaan dengan perkembangan madrasah dari masa ke masa, komplek pemondokan untuk tempat tinggal santri juga terus mengalami pertumbuhan. Tempat tinggal santri yang pada masa awal berdirinya Pondok Pesantren Krapyak hanya berupa gothakan atau kamar tempat tinggal santri lama kelamaan berkembang menjadi komplek-komplek yang dapat menampung puluhan hingga ratusan santri. Komplekkomplek di Krapyak yang dinamakan sesuai urutan abjadiyah kini telah mencapai 23 komplek dengan total 2000-an orang santri. ${ }^{29}$

Pondok Pesantren Al-Munawwir Komplek Q Krapyak Yogyakarta merupakan pondok pesantren khusus putri bagi pelajar dan mahasiswi yang bertempat di Kota Pendidikan Yogyakarta. Komplek Q tersebut berlokasi tidak jauh dari pusat-pusat pendidikan di Yogyakarta, PP. Al-Munawwir Komplek Q memberi kesempatan bagi generasi muda untuk memperdalam agama Islam sambil menimba ilmu di institusi pendidikan formal yang ada. Komplek ini didirikan tanggal 22 September 1989 oleh KH. Ahmad Warson Munawwir sebagai salah satu bagian dari PP. Al-Munawwir Krapyak Yogyakarta. Dalam Komplek Q ini menyelenggarakan kajian kitab kuning (turats) serta program tahfidzul quran dengan sanad yang diperoleh dari maha guru Alquran KH. M. Munawwir. ${ }^{30}$

Adapun program yang terdapat di Tahfidzul quran Pondok Pesantren Al-Munawwir Komplek Q Krapyak Yogyakarta terdiri dari dua program. Pertama, Tahfidzul Qur'an. Program ini khusus diperuntukkan bagi santri yang menghafal Alquran 30 juz. Tahfidzul

${ }^{28}$ http://www.sajadah.co/sejarah-pondok-pesantren-krapyak-yogyakarta/ diakses pada 04 Mei 2019: 23.05 .

${ }^{29}$ http://www.sajadah.co/sejarah-pondok-pesantren-krapyak-yogyakarta/ diakses pada 04 Mei 2019:

${ }^{30} \mathrm{http} / / /$ almunawwirkomplekq.com/profil/ diakses pada 05 Mei 2019: 04.30. 
quran diampu secara langsung oleh pengasuh PP. Al-Munawwir Komplek Q yaitu Nyai Hj. Husnul Khotimah Warson beserta putra putri beliau, KH. Muhammad Fairuz Warson dan Nyai $\mathrm{Hj}$. Qorry Aina Warson. Untuk mengikuti program ini, santri diwajibkan mengikuti seleksi. Kedua, Pengajian Umum. Pengajian umum adalah sistem pengajian bandongan kitab kuning yang wajib diikuti oleh seluruh santri baik yang mengikuti program Madrasah Salafiyyah III maupun Program Tahfidzul quran. Pengajian tersebut dilakukan secara berkala pada pagi dan sore hari yang diampu oleh para ustadz senior. Ketiga, Program Pendidikan Madrasah Salafiyyah III. Pembelajaran pada Madrasah Salafiyyah III menggunakan sistem klasikal yang diselenggarakan rutin setiap ba'da maghrib di Madrasah Salafiyyah III, santri dikelompokkan menjadi 6 kelas menurut kemampuannya dan diatur dengan kurikulum sesuai dengan jenjangnya. Madrasah Salafiyyah III didukung oleh para pengajar/ustadz dan ustadzah yang berkompeten baik dari keluarga pengasuh, alumni, maupun santri senior PP. AlMunawwir Krapyak Yogyakarta. Adapun kurikulum Madrasah Salafiyyah III terdiri dari: Alquran, Ilmu Tajwid, Ilmu Tafsir, Ilmu Tauhid, Ulumus syari'ah, Ushul Fiqh, Fiqh, Qawaid Fiqhiyah, Akhlaq/Tasawuf, Ulumul Lughoh, Nahwu, Shorof, Bahasa Arab, Tarikh, Praktek Ibadah, Qiroatul Kutub, Batsul Masail. Selain pembelajaran klasikal di kelas, santri Madrasah Salafiyyah III turut serta diwajibkan mengikuti pengajian Alquran dan sorogan kitab kuning secara individu baik kepada pengasuh maupun raisah.

Adapun fasilitas pendidikan yang disediakan berupa Lemari \& Loker Pribadi, Kamar, Mushola \& Aula, Ruang Kelas yang Representatif, Perpustakaan, Pos Kesehatan Pesantren (POSKESTREN), Kantin \& Minimarker (Q-mart), Depot air minum Moya-Q yang teruji secara klinis, Tempat parkir yang memadai dan Ruang belajar yang nyaman. Selain itu, Kegiatan Penunjang di Pondok Pesantren Al-Munawwir Komplek Q Yogyakarta antara lain Haflah Khotmil quran, Wisuda Madrasah Salafiyyah III, Rihlah \& Study Komparatif Pesantren, Peringatan Harlah Komplek Q, Program Khusus Ramadhan, Orientasi Studi \& Pengenalan Pesantren (OSPEP), Ekstrakulikuler (Hadroh, Qiroah, Kaligrafi), Ziaroh Maqbaroh, Mujahadah, Pembacaan Diba'/Barzanji/Burdah/Simtuduror, Senam, Bakti sosial dan kegiatan lainnya. ${ }^{31}$

${ }^{31} \mathrm{http}: / /$ almunawwirkomplekq.com/profil/ diakses pada 05 Mei 2019: 04.30. 


\section{Bentuk dan Pengembangan Birokrasi Pondok Pesantren Al-Munawwir Komplek Q}

\section{Krapyak Yogyakarta}

Pondok Pesantren Al-Munawwir Krapyak Yogyakarta yang terletak di Jalan KH Ali Maksum Tromol Pos 5 RT.05 Krapyak Kulon Panggungharjo Sewon Bantul Daerah Istimewa Yogyakarta memiliki 23 komplek yang masing-masing kompleknya dapat mencapai ratusan atau puluhan santri, dan salah satu komplek santri terbanyak untuk putri berada di Komplek Q yang tak jauh dengan Pondok Pesantren Al-Munawwir Krapyak. Komplek Q ini berada di Jalan KH. Ali Maksum, Krapyak, Panggungharjo Sewon Bantul Daerah Istimewa Yogyakarta dengan memiliki jumlah santri sekitar 342 santri yang belum termasuk hitungan santri barunya. Pada Pondok Pesantren ini santri tidak hanya terdiri dari mayoritas mahasiswa saja, akan tetapi juga terdiri dari santri hafalan (tahfidz) dari kelas 1-6 SD sebanyak kurang lebih 56 anak di Komplek Q tersebut.

Dalam bentuk dan pengembangan birokrasi pondok pesantren Al-Munawwir Komplek Q Krapyak Yogyakarta secara struktural berada di bawah naungan Ibu Pengasuh yaitu Bu Nyai Hj. Khusnul Khotimah Warson, kemudian Dewan Pengarah yang terdiri dari Kepala Madrasah, Pembimbing SMK, Perwakilan Ustadz, Perwakilan Pengurus Pusat, Perwakilan Alumni dan Ketua Demisioner yang membawahi Raisah sekaligus selaku Ketua Santri atau Badan Pengurus Harian (BPH) yang mana merupakan santri di komplek tersebut dan bertanggung jawab dalam menyusun, menjalankan serta mengevaluasi program pondok khususnya di Komplek Q yang terdiri atas Ketua, Wakil Ketua I (membawahi divisi vital atau urgent seperti divisi Keamanan, Kebersihan dan Kesehatan serta Ibadah Jam'iyyah), Wakil Ketua II (membawahi divisi Media dan Publikasi, Pengembangan Ekonomi serta Perpustakaan), Wakil Ketua III (membawahi divisi Pengembangan Sumber Daya Santri, Tahfidz serta Pengajian Al-Qur'an), Sekretaris I dan II serta Bendahara I, II, dan III. Selanjutnya Badan Pengurus Harian membawahi divisi Ketua Rayon dan Kebersihan Kepedulian Lingkungan yang terdiri atas 8 kamar atau dapat dikatakan sebagai koordinator kamar yang bertanggung jawab terhadap santri yang berada di masing-masing kamarnya tersebut. Ketua Rayon disini berfungsi untuk menjembatani komunikasi antara santri dengan santri badan pengurus harian tersebut. Secara sederhana, Badan Pengurus Harian ini dipilih berdasarkan tim formatur yang terdiri dari Raisah lama dan BPH lama saat akan Rapat Akhir Kepengurusan. Kriteria dasar yang ditunjuk sebagai Badan Pengurus Harian haruslah terlebih dahulu mengikuti ospek Pondok dan BPH lama melihat track record calon BPH baru dengan 
pertimbangan kinerja sebelumnya. Hal ini bertujuan sebagai monitoring terhadap kaderisasi pengurus selanjutnya.

Untuk mengetahui struktur birokrasi kelembagaan Komplek Q tersebut dapat dilihat berdasarkan susunan struktur di bawah ini:

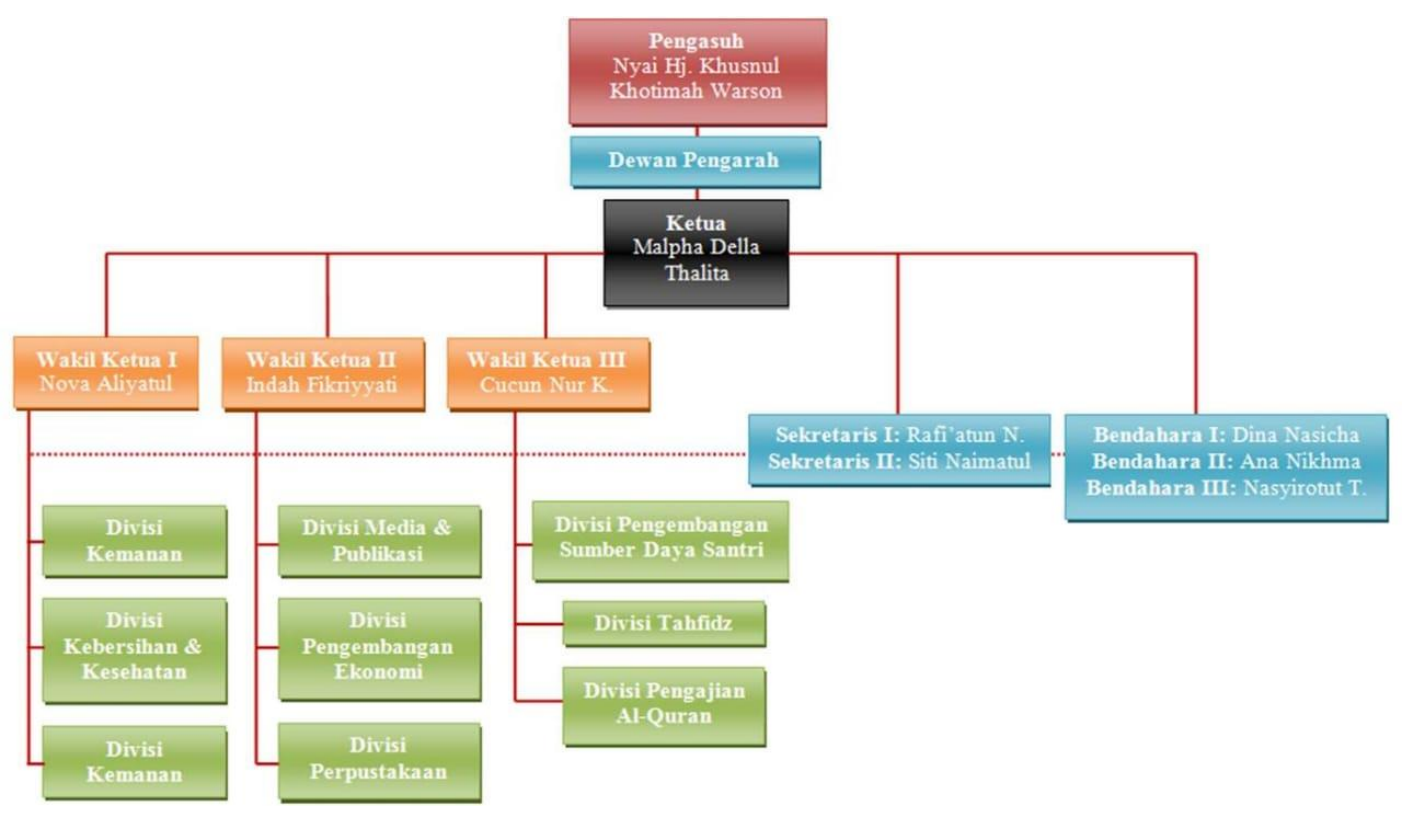

Struktur birokrasi di atas, memberikan beberapa gambaran pokok: Pertama, $\mathrm{Bu}$ Nyai selaku pengasuh Komplek Q pemegang kekuasaan tertinggi dan berhak menggunakan wewenang dan peraturan kelembagaan pendidikan di komplek tersebut. Kedua, Dewan pengarah merupakan pelanjut kebijakan $\mathrm{Bu}$ Nyai serta memiliki hak untuk menentukan peraturan dan kebijakan lainnya dalam memberikan controlling dan perannya dalam mengembangkan program-program pendidikan Islam. Keempat, fungsi raisah atau ketua seluruh santri sekaligus selaku Badan Pengurus Harian mengontrol jalannya birokrasi dan program-program pondok pesantren Al-Munawwir Krapyak khususnya di Komplek Q serta terkait kebijakan lainnya. Kelima, wakil ketua bidang I, II dan III yang membawahi masing-masing divisi serta sekretaris dan bendahara berfungsi selaku fungsi praksis dalam administrasi organisasi dan pembiayaan. Keenam, Ketua Rayon dan Kebersihan Kepedulian Lingkungan masing-masing kamar selaku koordinator di setiap kamarnya.

Adapun secara struktural kekuatan birokrasi lembaga ini sangatlah jelas. Namun, di lain sisi secara independen peranan Raisah dan pengurus lainnya disini sebagai badan eksekutor selaku menjalankan tugas dan kewajiban pondok dalam menyusun rencana program, mengatur, menjalankan, evaluasi dan lain-lainnya tetap harus dikomunikasikan dengan Ibu pengasuh sehingga $\mathrm{Bu}$ Nyailah yang mempunyai wewenang dalam hal 
pengambilan keputusan dan kebijakan. Dalam hal ini, sama halnya dengan sistem demokrasi terpimpin yang mana merupakan sebuah sistem demokrasi dan seluruh keputusan akhir berpusat pada Ibu Pengasuh selaku pemegang hak otoritas tertinggi di Komplek Q, namun tetap mengedepankan sistem demokrasi dalam prosesnya. Hal ini terbukti dalam pemilihan Raisah yang mana diberlakukannya pesta demokrasi dengan diberikannya kebebasan para santri untuk memilih dan menentukan pilihannya. Secara prosedural, pemilihan Raisah dipilih saat Rapat Akhir Kepengurusan atau saat rapat demisioner pengurus lama, para pengurus tersebut menyebarkan kertas ke setiap kamar untuk diberikannya kebebasan masing-masing santri dalam menentukan pilihannya. Setelah nama tersebut terkumpul, dipilihlah 10 orang dengan suara terbanyak untuk dikomunikasikan kepada bu Nyai dan bu Nyai memilih 3 nama yang akan menjadi kandidat dari Raisah di Komplek Q tersebut hingga diadakannya kampanye untuk melihat kapabilitas dari masing-masing kandidat. Selama seminggu, terdapat poster yang dipajang dari nama-nama kandidat tersebut dan masing-masing rayon atau kamar membuat yel-yelan untuk calon yang didukungnya. Dan di akhir kampanye, masing-masing santri menetapkan satu dari 3 pilihan calon tersebut dengan cara voting dan di akhir pesta demokrasi tersebut nama yang memperoleh suara terbanyak dikomunikasikan kembali kepada bu Nyai untuk mendapatkan restu ataupun persetujuan sebagai Raisah di Komplek Q tersebut.

Sebagai unsur pimpinan dalam menjalankan tugas dan kewajibannya, Raisah selaku ketua santri di Komplek Q Pondok Pesantren Al-Munawwir Krapyak dalam pengembangan birokrasi kelembagaan menjalankan dua strategi kepemimpinan yakni, Pertama melalui pendekatan dialogis artinya semua hal yang berkaitan dengan tugas dan tanggung jawab anggota, sebagai Raisah selalu mengedepankan musyawarah, sharing ataupun diskusi, sehingga semua keputusan yang dijalankan oleh anggota berdasarkan hasil kesepakatan bersama. Kedua, strategi rolling job atau pembagian tugas program kerja secara bergiliran dalam pelaksanaan kegiatan pondok yang ditunjuk sebagai ketua panitianya misalnya santri 'A', maka untuk kepanitiaan selanjutnya akan diberikan kepada santri 'B' yang berbeda begitupun seterusnya. Hal ini bertujuan untuk menghindari double job atau penumpukan beban kerja pada satu orang saja dan setiap anggota dapat merasakan peranan kerja dan terbiasa untuk bertanggung jawab.

\section{Pengembangan Perilaku Pondok Pesantren Al-Munawwir Krapyak Komplek $Q$ Yogyakarta}

Pondok Pesantren Al-Munawwir Krapyak Yogyakarta khususnya komplek Q adalah lembaga pendidikan Islam yang mengembangkan unsur-unsur pendidikan yang bercirikan 
islami, ilmu, kreativitas, akhlak dan budaya. Dalam membangun perilaku organisasinya ada beberapa landasan yang dijadikan nilai dasar kelembagaan yakni Pertama, perilaku Islami dimana Islam menjunjung tinggi sikap saling menghormati, karena terkadang dalam organisasi pasti muncul rasa persaingan antara individu yang satu dengan yang lainnya, sehingga sikap saling menghormati adalah bentuk pengamalan nilai-nilai Islami yang berlandaskan al-Qur'an dan Hadits. Kedua, nilai-nilai kejujuran dalam diri setiap anggota, sebagai seorang santri dalam mengikuti pengajian dengan tidak membolos dan kejujuran dalam hal perizinan, sikap kejujuran ini nantinya akan diajarkan dan menjadi contoh bagi santri lainnya. Di lain sisi, nilai kejujuran disini dalam hal transparansi dana dengan selalu mengupdate berapa debet, kredit dan sisa saldo dari SPP bulanan yang dibayarkan oleh para santri. Ketiga, kedisiplinan juga merupakan bagian yang sifatnya wajib dikarenakan untuk memberikan contoh dan suri tauladan kepada santri lainnya baik dalam hal ketepatan waktu beribadah maupun pengajian di setiap ba'da shubuh di hari Senin, Selasa, dan Sabtu dengan pengajian Al-Qur'an sistem sorogan dengan Ra'isah masing-masing dan di hari lainnya dengan sistem bandongan dengan satu ustadzah mengajari santri bersama-sama. Tidak hanya pengajian ba'da subuh, namun pula pengajian ba'da maghrib hingga pukul 22.00 atau 22.30 WIB di setiap malamnya dengan pelajaran akhlak, tajwid dan lain sebagainya yang terdiri atas enam kelas yaitu kelas I'dad, Awwal, Tsani, Tsalits, Rabi', Khomis (adanya munaqasyah dan tugas TA hingga wisuda) dan kelas paling tinggi yaitu kelas pasca atau pengabdian yang sudah memilki banyak keilmuan sehingga dapat mengajarkan santri. Bentuk pendisiplinan saat jam pengajian tersebut dengan tidak diperkenankannya mengaktifkan handphone yang benarbenar mencerminkan perilaku disiplin khususnya dalam menghargai waktu. Oleh karenanya, disiplin menjadi bagian terpenting yang haruslah dibiasakan. Pendisiplinan disini dengan diberlakukannya pula sistem penta'ziran untuk santri yang melanggar peraturan pondok pesantren di komplek Q. Hal ini sesuai dengan yang dikatakan oleh Ra'isah santri Komplek Q:

"Di komplek $Q$ ini ada banyak santri bahkan jumlahnya mencapai ratusan santri, dan kami tentu tidak menafikkan pastinya ada santri yang disiplin dan kurang disiplin dalam menjalankan kegiatan pondok. Oleh karenanya, kami selalu mengadakan pengontrolan di setiap kamar ketika jam jama'ah dan pengajian. "32

${ }^{32}$ Hasil wawancara dengan Malpha Della Thalita, Raisah Komplek Q Ponpes Al Munawwir Krapyak, 04 Mei 2019, pukul 11.00 WIB di asrama pengurus komplek Q Krapyak Yogyakarta. 


\section{Budaya Organisasi Pondok Pesantren Al-Munawwir Komplek Q Krapyak Yogyakarta}

Pondok Pesantren merupakan pusat pembelajaran, dakwah dan pemberdayaan masyarakat yang mana sebagai lembaga pendidikan Islam tertua di Indonesia pesantren memainkan peran sangat penting dalam sejarah pendidikan di Indonesia. Pesantren juga menyediakan media sosialisasi formal di mana norma dan nilai Islam ditransmisikan dan ditanamkan melalui berbagai aktivitas pengajaran.

Secara faktual perkembangan pondok pesantren di Indonesia dapat dibedakan menjadi tiga bentuk, yaitu: 1) Salaf atau tradisional, 2) Khalaf atau modern, 3) Komprehensif atau kombinasi. Pertama, pesantren ini masih mempertahankan bentuk aslinya sebagaimana berlangsung sejak awal kemunculannya dengan semata-mata mengajarkan kitab-kitab kuning yang ditulis oleh ulama klasik pada abad pertengahan menggunakan bahasa Arab. Model pengajarannya dapat berbentuk sorogan ataupun bandongan dan jenjang pendidikan tidak berdasarkan tingkatan waktu melainkan dengan selesai atau khatamnya suatu kitab tertentu dan santri dapat naik ke jenjang berikutnya dengan mempelajari tingkat kesulitannya yang lebih tinggi dari sebelumnya begitu pun seterusnya. Kedua, pesantren khalaf ataupun modern, pondok pesantren ini menyelenggarakan kegiatan pendidikan dengan pendekatan modern melalui kegiatan formal, baik madrasah (MI, MTs, MA), maupun sekolah (SD, SMP, SMA, SMK) atau nama lainnya tetapi dengan pendekatan jenjang kelas dengan satuan program didasarkan pada satuan waktu. Pengajaran kitab-kitab Islam klasik tidak diselenggarakan. Sekalipun bahasa Arab diajarkan, namun penguasaannya tidak diarahkan untuk memahami bahasa Arab yang terdapat dalam kitab-kitab klasik. Penguasaan bahasa Arab dan Inggris cenderung ditujukan untuk kepentingan-kepentingan praktis. Ketiga, pesantren komprehensif atau kombinasi, pondok pesantren yang menyelenggarakan pendidikan secara komprehensif karena memadukan sistem pendidikan dan pengajaran gabungan antara tradisional dan modern dengan kurikulum lengkap.

Dalam membangun budaya organisasinya, Pondok Pesantren Al-Munawwir Krapyak Komplek Q masih sangat menjaga dan mempertahankan budaya daerahnya yang mana merupakan daerah dengan suku Jawa yang sangat mempertahankan akulturasi budaya dan bahasanya. Hal ini dapat terlihat pada pelaksanaan pengajian kitab kuning yang menggunakan bahasa Jawa Pegon dalam me-lugot dan diharuskan menggunakan bahasa Jawa dalam berkomunikasi sehari-hari baik kepada dewan pengasuh maupun kepada sesama santri. Hal ini dilaksanakan agar nilai-nilai tradisi masyarakat tidak akan tergerus oleh perubahan sosial, serta para santri yang berasal dari seluruh nusantara yang tidak memahami dan mengerti bahasa Jawa sudah diperkenalkan dengan nilai-nilai kebudayaan Jawa dengan penggunaan 
bahasa sehari-hari. Dan hal tersebut dirasakan lebih mampu membangun nilai-nilai kekeluargaan antara sesama santri khususnya di Komplek Q Pondok Pesantren Krapyak tersebut.

Berbagai indikator di atas, merupakan tujuan yang disusun oleh lembaga pendidikan Islam Pondok Pesantren Al-Munawwir Krapyak Komplek Q untuk mencapai sasaran program yang telah direncanakan. Selain memperkuat perilaku dan budaya organisasinya, dalam memajukan jaringan kelembagaan Pondok Pesantren Al-Munawwir Krapyak Komplek Q juga membangun kerja sama dengan komplek lainnya. Hal ini terbukti saat acara muharoman yang diadakan setiap setahun sekali sebagai fungsi sosialisasi antar komplek agar para santri dapat saling mengenal dengan komplek lainnya dan menjaga ukhuwah Islamiyah di Pondok Pesantren Al-Munawwir Krapyak Yogyakarta.

\section{Kesimpulan}

Lembaga pendidikan Islam membutuhkan rantai birokrasi dalam pengembangan kelembagaan sebagai sarana untuk pembagian kerja, struktur, peraturan, kebijakan dan kebutuhan lainnya. Dimana birokrasi menjadi jembatan untuk mentransfer tugas dan kewajiban kelembagaan, sementara budaya organisasi adalah kepribadian organisasi yang mempengaruhi cara bertindak individu dalam organisasi, kemudian budaya organisasi membentuk nilai, norma-norma perilaku, ideologi, sikap, kebiasaan, dan harapan-harapan yang dimiliki oleh organisasi.

Penguatan perilaku dan budaya organisasi yang khas dalam lembaga pendidikan Islam adalah sumber nilai, tata kehidupan, dan ciri tertentu yang membedakan lembaga tersebut dengan lembaga-lembaga lainnya. Budaya dan perilaku kependidikan selalu mengutamakan transfer nilai di dalam lembaganya sehingga keutuhan lembaga bisa dijaga dengan baik.

Pondok Pesantren Al-Munawwir Komplek Q adalah salah satu struktur lembaga pendidikan Islam yang sangat memperhatikan pelaksanaan birokrasinya, pengembangan perilaku dan budaya organisasinya. Berdasarkan uraian tersebut, dapat diketahui bahwasanya dalam mengembangakan birokrasi, perilaku dan budaya organisasinya, beberapa hal yang dapat disaring seperti: Pertama, birokrasi kelembagaan di Pondok Pesantren Al-Munawwir Komplek Q bersifat dialogis yang mana dalam pembagian struktur, tugas dan unsur kelembagaan dirumuskan melalui ruang diskusi ataupun musyawarah. Hal ini bertujuan sebagai bentuk tugas dan tanggung hawab dapat diemban dan diputuskan bersama-sama. Kedua, strategi rolling job merupakan bentuk keseimbangan tugas dan tanggung jawab bagi semua anggota agar tidak terjadi double job pada satu orang saja. Ketiga, nilai-nilai moral 
Nur Ita A’ini Qudwatal Millah dan Nove Kurniati Sari

keislaman seperti bersikap toleran, jujur, disiplin dan bertanggung jawab adalah nilai yang harus dibangun dalam organisasi ini agar terbangun komunikasi dan kerjasama harmonis. Keempat, mempertahankan budaya masyarakat Jawa dengan membiasakan berkomunikasi menggunakan bahasa daerah agar menanamkan nilai kebudayaan serta membangun rasa ukhuwah dalam berorganisasi.

\section{Daftar Pustaka}

Albrow, Martin, Birokrasi, Terj. M. Rusli Karim, (Yogyakarta: Tiara Wacana, 1996).

Fatah, Eep Saefulloh, Catatan Atas Gagalnya Politik Orde Baru, (Yogyakarta: Pustaka Pelajar, 1998).

Hafidhuddin, Didin dan Hendri Tanjung, Manajemen Syariah dalam Praktik, (Jakarta: Gema Insani Press, 2003).

Imawan, Riswanda, Membedah Politik Orde Baru, (Yogyakarta: Pustaka Pelajar, 1998).

Komariah, Aan dan Chepi Triatna, Visionary Leadership: Menuju Sekolah Efektif, (Bandung: Bumi Aksara, 2006).

Purwanto, Ngalim, Budaya Perusahaan, (Yogyakarta: Pustaka Pelajar, 2008).

Robbins, Stephen P., Teori Organisasi: Struktur, Desain, dan Aplikasi, (Jakarta: Penerbit Arcan, 1994).

., dan Coulter, Mary, Manajemen, Edisi Bahasa Indonesia, Sixth Edition, (Jakarta: PT.Prenhallindo, 1999).

Saefullah, U., Manajemen Pendidikan Islam, (Bandung: Pustaka Setia, 2012).

Sedarmayanti, Sumber Daya Manusia dan Produktivitas Kerja (Bandung: CV. Mandar Maju, 2009).

Siagian, Sondang P., Kiat Meningkatkan Produktivitas Kerja, (Jakarta: Penerbit Rineka Cipta, 2002).

Sumarwan, Ujang, Perilaku Konsumen: Teori dan Penerapannya dalam Pemasaran. (Jakarta: Penerbit Ghalia Indonesia, 2003).

Syafar, Djunawir, Birokrasi, Perilaku dan Budaya Organisasi dalam Lembaga Pendidikan

Islam Roudlotul Athfal UIN Sunan Kalijaga Yogyakarta, Manageria: Jurnal Manajemen

Pendidikan Islam Vol 2, NO 2, November 2017.

Thoha, Miftah, Birokrasi dan Politik di Indonesia, cet. 2, (Jakarta: Raja Grafindo Persada, 2003).

Torang, Syamsir, Metode Riset Struktur dan Perilaku Organisasi, (Bandung: CV Pustaka, 2012).

Umam, Khaerul, Perilaku Organisasi Cetakan I, (Bandung: Pustaka Setia, 2010).

Weber ,Max, From Max Weber: Essays in Sociology, H. Gerth and C. Wright Mills, eds., (New York: Oxford University Press, 1947).

Wirawan, Budaya dan Iklim Organisasi: Teori, Aplikasi dan Penelitian, (Jakarta: Salemba Empat, 2007). 
Birokrasi dan Perilaku Budaya Organisasi Di Pesantren

Wursanto, Dasar-dasar Ilmu Organisasi, (Yogyakart; Andi Offset, 2005).

\section{Sumber Internet}

http://almunawwirkomplekq.com/profil/ diakses pada 05 Mei 2019: 04.30.

http://www.sajadah.co/sejarah-pondok-pesantren-krapyak-yogyakarta/ diakses pada 04 Mei 2019: 23.05. 